\title{
Gametogenesis and reproductive behavior in the echinoid Lytechinus variegatus
}

\author{
Daniel A. McCarthy* , Craig M. Young \\ Department of Larval Ecology, Harbor Branch Oceanographic Institution, 5600 US Hwy 1 N., Ft. Pierce, Florida 34946, USA
}

\begin{abstract}
Gametogenesis and behavior facilitating reproduction were studied in the echinoid Lytechinus variegatus (Lamark 1816), found off Key Biscayne, Florida, during 1993. Oocyte diameters and qualitative staging of gonad sections indicated a sustained peak in reproductive state from April to June followed by a decrease in reproductive state by August and a shorter reproductive peak by November. Ripe females censused during both reproductive seasons showed substantial variation in oocyte size suggesting that sporadic, small scale spawning events commonly occur in this population. Counts of urchins in nested quadrats showed that $L$. variegatus aggregates at no fewer than 4 different spatial scales $\left(0.0625,0.25,1.0\right.$, and $\left.2.0 \mathrm{~m}^{2}\right)$ with aggregations at larger scales being most common, especially prior to reproductive seasons. A noticeably higher amount of food in guts at these times suggests that these aggregations may be formed during random encounters during periods of increased feeding activity, which may also build up energy reserves for reproduction. Marked urchins were arranged in artificial aggregations of various sizes to investigate potential reproductive interactions. Most urchins moved 1 to $3 \mathrm{~m} \mathrm{~d}^{-1}$ throughout the year. Most encounters among urchins were of short duration and occurred randomly. Urchins placed in the largest aggregations dispersed most slowly during April and June, the periods with the highest mean oocyte diameters. The incidence of heterosexual pairing among naturally occurring pairs of urchins was random, suggesting that $L$. variegatus may not be able to distinguish gender. Sex ratio of the population was skewed in favor of males. The data suggest that numerous small scale spawning events take place during an extended reproductive season and that intraspecific encounters occur during this season entirely by chance. This method of spawning may enhance outcrossing.
\end{abstract}

KEY WORDS: Aggregations · Behavior $\cdot$ Lytechinus $\cdot$ Gametogenesis $\cdot$ Movement $\cdot$ Echinoid

Resale or republication not permitted without written consent of the publisher

\section{INTRODUCTION}

Marine invertebrates with external fertilization probably waste an enormous proportion of their reproductive effort. Thorson (1950) hypothesized that nearly all gametes successfully fertilize and that most reproductive loss occurs as mortality during the planktonic phase of larval development. Recent studies suggest, however, that fertilization failure can account for a substantial portion of the wastage (Pennington 1985, Denny 1988, Denny \& Shibata 1989, Yund 1990, Brazeau \& Lasker 1990, Levitan 1991b, 1995, Levitan

*E-mail: mccarthy@sms.si.edu et al. 1992, Sewell \& Levitan 1992). It has been suggested that motile broadcast spawners have an advantage over sessile spawners because the former can move into close proximity with other individuals for spawning and thus enhance fertilization success (Giese \& Kanatani 1987, Levitan 1991a). Behavior facilitating reproduction could potentially exist at various temporal and spatial scales and any number of strategies could work for broadcast spawners.

Large scale seasonal aggregations have been observed among motile broadcast-spawning echinoderms (Elmhirst 1922, Lewis 1958, Moore et al. 1963, Dix 1969, Pearse \& Arch 1969, Camp et al. 1973, Mattison et al. 1977, Levitan 1988, Unger \& Lott 1994), although mass spawning has seldom been observed in 
these species. Aggregations may enhance reproduction but may also enhance feeding efficiency (Grassle et al. 1975, Mattison et al. 1977, Garnick 1978, Witman et al. 1982, Vadas et al. 1986, Unger \& Lott 1994). The sea urchin Sphaerechinus granularis forms large scale aggregations (30 individuals) that remain together for several days (Unger \& Lott 1994). Natural spawning was not observed in this species, although members of the aggregations were always more ripe than solitary individuals in the same population, strongly suggesting that the aggregations are for reproductive purposes. Mass spawnings have been stimulated experimentally in aggregations of $S$. granularis by artificially inducing a single male to spawn (Unger \& Lott 1994).

Small scale seasonal aggregations (usually pairs) have been observed in several motile free-spawners that normally occur at low population densities (Orton 1914, Moore et al. 1963, Dix 1969, Komatsu 1983, Run et al. 1988, Tyler \& Young 1992, Tyler et al. 1992, Young et al. 1992). The sea star Archaster typicus (Komatsu 1983, Run et al. 1988), the deep-sea urchin Stylocidaris lineata (Young et al. 1992) and the deepsea holothurian Paroriza pallens (Tyler et al. 1992) all aggregate during their respective reproductive seasons. In $S$. lineata, individuals found in aggregations are usually ripe, whereas solitary individuals are not (Young et al. 1992). These small scale aggregations presumably remain together throughout much of the reproductive season. Young et al. (1992) suggested that where the chances of finding a mate are poor, a free-spawner can ensure reproduction by maintaining close contact with the first conspecific found while awaiting the cue to spawn. This strategy is even advantageous for hermaphroditic species such as $P$. pallens, which can presumably breed with any conspecific encountered (Tyler et al. 1992). Gonochoristic species such as $A$. typicus and $S$. lineata can only breed successfully with conspecifics of the opposite sex, so reproductive effort would be lost in homosexual pairs except where male pairing serves to increase sperm concentration and hence fertilization success during a mass spawning event (Young et al. 1992). A. typicus (Komatsu 1983, Run et al. 1988) can apparently discriminate between genders, unlike sea urchins, which do not appear to have this ability (Dix 1969, Young et al. 1992). Even when gender cannot be assessed, however, the statistical likelihood of successful fertilization is greater in random pairings than in isolation. Species living at higher densities may successfully employ a reproductive strategy of either mass spawning or sporadic spawning during numerous intraspecific encounters that occur during the reproductive season.

The sea urchin Lytechinus variegatus is a broadcast spawner commonly found in seagrass beds throughout the Southeastern United States and Caribbean. Moore et al. (1963) observed aggregations on several size scales during the peak reproductive season (February to March) whereas Montague et al. (1977) found the statistical dispersion of the same population to be random when censused in September. These early studies suggest that this population of $L$. variegatus may aggregate seasonally to enhance reproductive success.

In the present study, we investigated gametogenesis and behavioral mechanisms facilitating reproduction in a population of Lytechinus variegatus in Biscayne Bay, Florida, not far from the population studied by Moore and Montague $35 \mathrm{yr}$ earlier. Our objective was to study simultaneously reproductive conditions and behavior, to determine if these 2 characteristics changed seasonally and in concert.

\section{MATERIALS AND METHODS}

Study area. Lytechinus variegatus was studied over a 1 yr period, from December 1992 through December 1993 off the SE shore of Virginia Key in Biscayne Bay, Florida (Fig. 1). Our study sites were on level bottoms approximately $1.5 \mathrm{~m}$ deep, and were covered homogeneously by seagrasses, primarily Thalassia testudinium and to a much lesser extent Syringodium filiforme and Halodule wrightii.

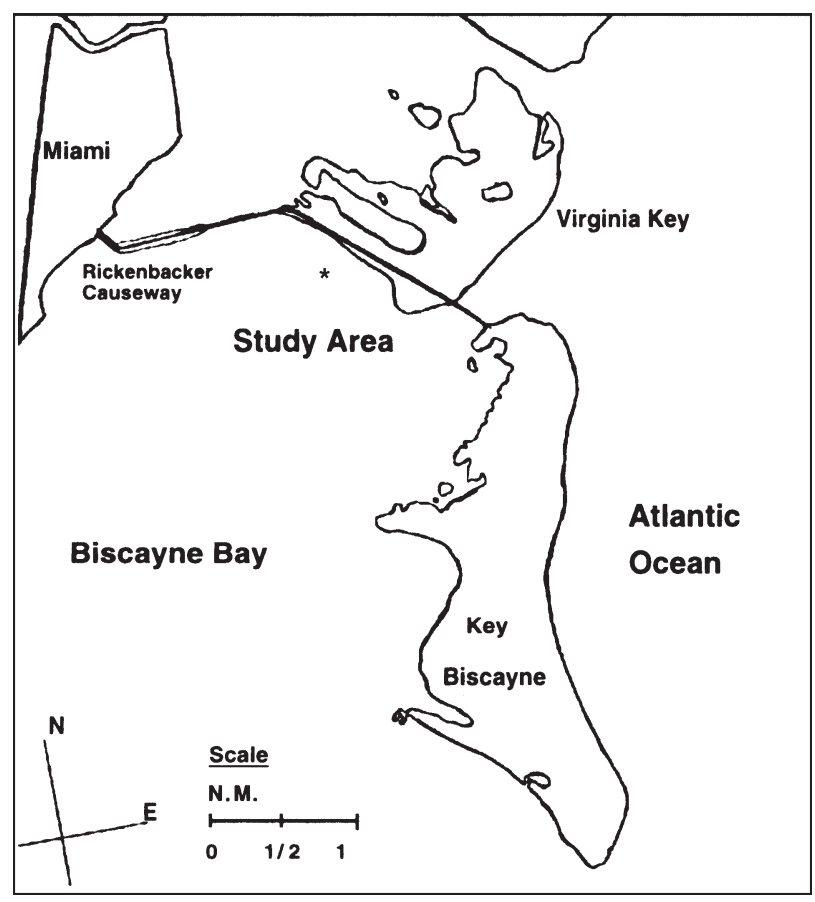

Fig. 1. Study sites (*) in Key Biscayne, Florida, were approximately $100 \mathrm{~m}$ apart and $175 \mathrm{~m}$ from shore in $1.5 \mathrm{~m}$ of water (mean low tide). N.M. = nautical mile 
Seawater temperature and seagrass biomass were monitored during the entire study. Seawater temperatures for a given census were based on the mean of the temperature measurements for each day of a given census. They were determined with a standard laboratory thermometer just above the substratum at a depth of approximately $1.5 \mathrm{~m}$. Seagrass biomass for a given census was the mean wet weight of all plant material harvested from 5 haphazardly thrown $25 \times 25 \mathrm{~cm}$ quadrats.

Reproductive periodicity. Twenty-five urchins were collected for each census, their test diameters measured and their coelomic fluid drained by carefully cutting holes in their tests. They were then weighed and the gonads were removed. The gonads of each urchin were then weighed and a gonadal index (percentage of gonad wet weight relative to total body weight) was calculated for each individual. Gonad indices were averaged among individuals within each census. A single gonad from each urchin was preserved in $10 \%$ buffered formalin and processed for paraffin sectioning using standard histological techniques. Sections were cut at $8 \mu \mathrm{m}$ and stained with Mallory's Triple stain. Oocyte area was measured for a minimum of 50 oocytes taken from each of 5 similarly sized females. Oocytes were measured at 100× magnification using Sigmascan image analysis software. To ensure independence of oocyte measurements, only oocytes with visible nucleoli were measured. In some cases, during the reproductive peaks, the nucleolus of the ripest oocytes were not visible, so instead we measured oocytes with a clearly contrasting nuclear membrane (P. Tyler pers. comm.). The area of each cell was converted to a theoretical diameter, as if the cell were perfectly round. A Kolmogorov-Smirnov 2-sample goodness-of-fit test was used to compare sequential distributions of oocyte sizes among successive collections. Gonads were also compared qualitatively using a gonad maturity index (Young et al. 1992).

Data from the staging of gonads were used to determine the extent of gametogenic synchrony between males and females of each census. A frequency distribution of the numbers of urchins that were in each of the stages (except for Stage $\mathrm{V}$ which was given the value of 1) of gonad maturation was constructed for each sex.

Synchrony among females within a census was determined by averaging oocyte size-frequency histograms for the 5 urchins from each census. These data were then analyzed by a Kruskal-Wallis test (Grant \& Tyler 1983b).

The sex ratio of the population was determined and used to assess whether naturally occurring pairs departed from the expected ratio using a G-test (Sokal \& Rohlf 1995).

Spatial distributions of populations. To investigate the potential relationship between scale of aggregation and reproductive state, Lytechinus variegatus were counted in nested quadrats on a $10 \times 10 \mathrm{~m}$ site with homogenous seagrass cover. Nested within the site were 1600 very small quadrats $(25 \times 25 \mathrm{~cm}), 400$ small quadrats $(50 \times 50 \mathrm{~cm}), 100$ medium quadrats $(1 \times 1 \mathrm{~m})$, and 25 large quadrats $(2 \times 2 \mathrm{~m})$, which represent aggregations at different spatial scales. An index of dispersion (variance:mean ratio) and mean urchin density were calculated for each quadrat size using 20 randomly chosen quadrats from each size (Krebs 1989). At each spatial scale, we computed Spearman correlation coefficients (Andrew \& Mapstone 1987, Sokal \& Rohlf 1995) for the index of dispersion against census means of oocyte diameter, gonad index, urchin size, seawater temperature, and wet weight of seagrass.

At each quadrat size and during each census, the frequency distribution of urchin counts was tested for goodness of fit to a Poisson distribution using the loglikelihood ratio (G-test) as a second measure of aggregation (Sokal \& Rohlf 1995). The results were then compared qualitatively among censuses.

Movement as a function of aggregation size. The net locomotory rate, mean distance between urchins and direction of movement for Lytechinus variegatus were studied in the field experiments shown diagramatically in Fig. 2. Forty-four urchins were placed at regularly spaced positions, $1 \mathrm{~m}$ apart, either alone or in groups of 2, 3 or 5 ( $\mathrm{n}=4$ for all sizes) to test whether aggregations of any particular size would be more likely to stay together during the reproductive season.

This field experiment was accomplished by clearing all sea urchins from an $8 \times 8 \mathrm{~m}$ site with uniform substratum. The starting point of each urchin or group of urchins was marked with a small, submerged fishing float that was numbered and attached to a weight with

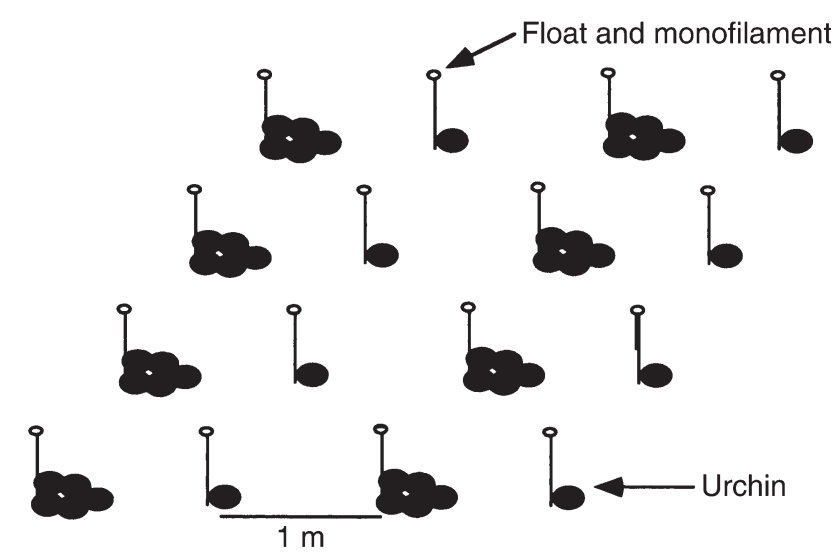

Fig. 2. Diagrammatic illustration of field experiments with marked urchins. Fishing floats marking the starting points were placed $1 \mathrm{~m}$ apart 
a short line. A $3 \mathrm{~m}$ wide buffer zone around each site was cleared of all conspecifics to reduce the likelihood of interference from extraneous individuals. Lytechinus variegatus in the 55 to $65 \mathrm{~mm}$ size class were then collected and individually marked by boring a tiny hole in the side of the test with a sharp dissecting needle and inserting a numbered upholstery tack tightly into the hole. A compass and tape were used to measure each individual's direction and distance from the start point after $10 \mathrm{~min}, 24,48$ and $72 \mathrm{~h}$. During each census, the number of marked individuals found in pairs, triplets, etc. was recorded and checked at the next census to determine how long these small aggregations remained. For this purpose, urchins were considered aggregated when they were found within $5 \mathrm{~cm}$ of each other.

The position of each urchin was mapped on each consecutive day of each census. A census mean of distances traveled for each of 3 consecutive days was calculated by taking the average of all urchins distances traveled from their last known position on the previous day. Nearest neighbor distances were averaged to determine the mean distance among urchins for each of the $3 \mathrm{~d}$ (Krebs 1989).

We correlated locomotory rates and nearest neighbor distances with oocyte diameter, gonad index, seawater temperature and seagrass biomass to investigate potential factors that could explain seasonal patterns. We tested for potential artifacts associated with the use of upholstery tack urchin tags by recording the distances marked and unmarked urchins moved after 10 and $60 \mathrm{~min}$ in the field. This experiment was run 5 times in the months of February, April, June, August and November. The data were analyzed using a 2factor (month, marking type) repeated measures (time) ANOVA (Sokal \& Rohlf 1995).

\section{RESULTS}

\section{Study area}

There was large seasonal variability in the water temperature at the study area. The lowest temperatures were approximately $20^{\circ} \mathrm{C}$ between December and February. The highest temperature was $30^{\circ} \mathrm{C}$ in the month of August. The seagrass biomass was fairly constant, averaging $23220 \mathrm{~g} \mathrm{~m}^{-2}$ (SD $=1515 \mathrm{~g} \mathrm{~m}^{-2}$ ) at all sites.

\section{Reproductive periodicity}

The mean of gonad index peaked in December $(0.0875)$ and decreased to the lowest value $(0.0285)$ by

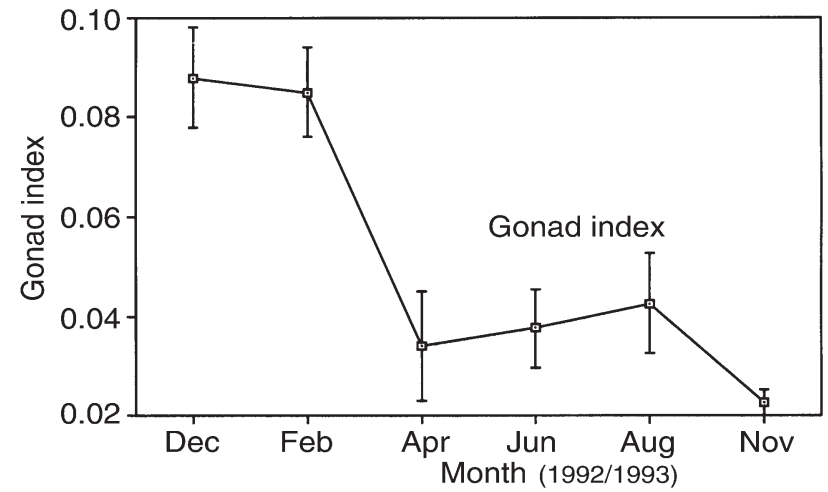

Fig. 3. Lytechinus variegatus. Gonad index (mean $\pm \mathrm{SD}$ ) in Key Biscayne, Florida
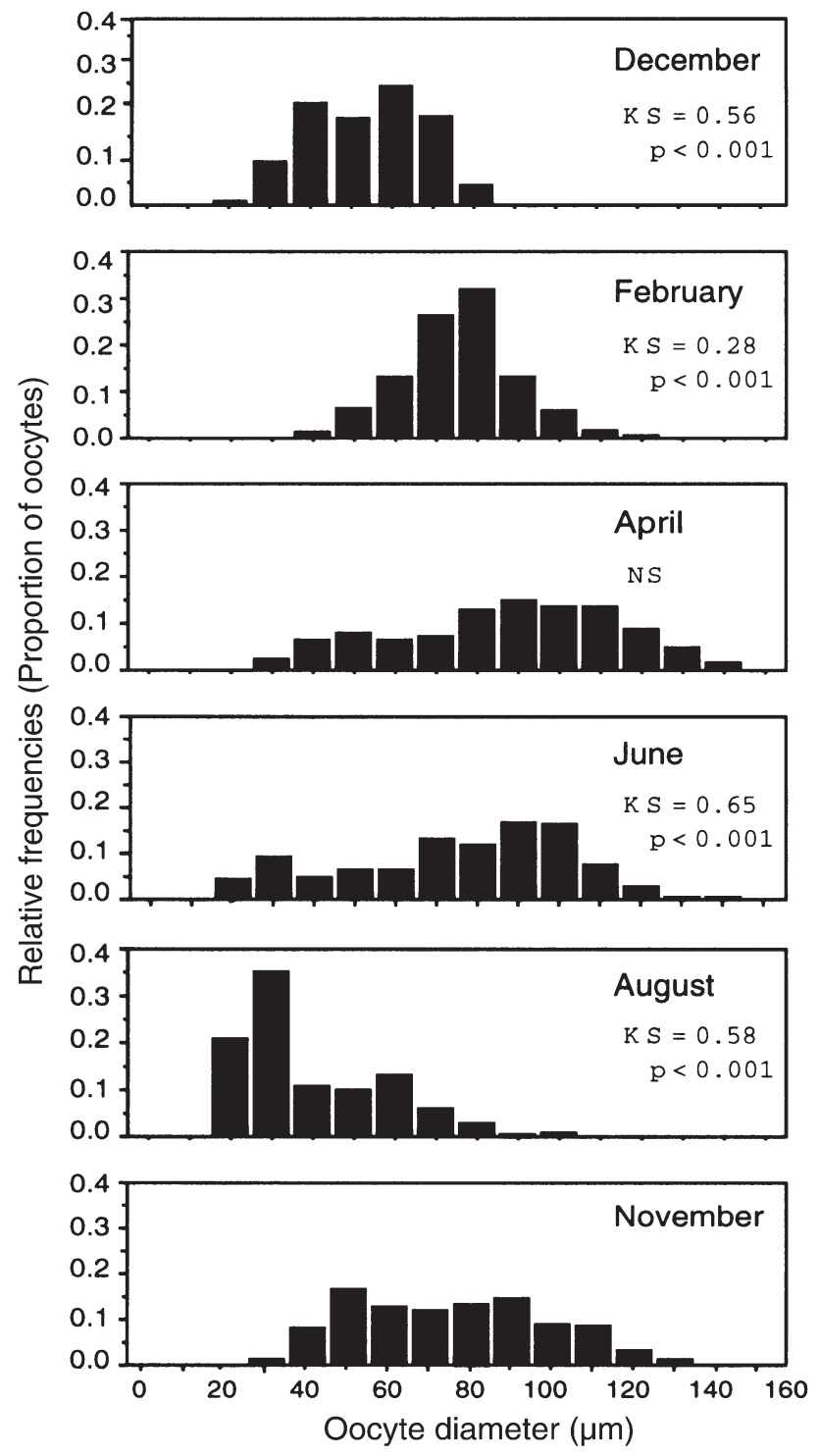

Fig. 4. Lytechinus variegatus. Relative frequencies of oocyte diameters for each month of the study. KS = KolmogorovSmirnov statistic $; \mathrm{NS}=$ not significant 
April (Fig. 3). There were decreases in gonad index between February and April censuses, and the August and November censuses. Relative frequencies of oocyte diameters for each collection of Lytechinus variegatus are shown in Fig. 4. Oocytes 40 to $80 \mu \mathrm{m}$ in diameter were typically present in the gonads year round. Larger oocytes 130 to $145 \mu \mathrm{m}$ in diameter were present only during April, June and November (month in which the ranges of oocyte sizes were also the greatest). Sequential distributions were significantly different between December and February ( $<0.001$ ), February and April $(\mathrm{p}<0.001)$, June and August $(\mathrm{p}<0.001)$, August and November $(\mathrm{p}<0.001)$, and November and December $(p \ll 0.001)$. Oocytes from the August sample were typically small and attached to the lumen with much empty space in the gonad, although some larger relict oocytes were also present.

The proportion of individuals having gonads at various stages of maturity is shown for each sex during each census in Fig. 5. The frequency distributions show higher values of maturity for both sexes during April, June, and November. The lowest values for both sexes occurred in August when there was also the lowest variation among individuals.
The frequency distributions of the maturity index did not differ significantly between sexes (Fig. 5) except during December and February. During these months, females generally had a higher maturity index than males.

The oocyte size distributions were found to be significantly different among the 5 individual female urchins in April, June and November (Fig. 6). The oocyte distributions of females in December and February tended to be more normally distributed, oocytes ranging between 30 and $100 \mu \mathrm{m}$ in diameter. The April and June distributions generally had larger ranges of oocytes of 40 to $150 \mu \mathrm{m}$ in diameter. August oocyte distributions were mostly normally distributed with a range of oocytes from 40 to $110 \mu \mathrm{m}$. November oocyte distributions generally had a broader range of oocyte diameters, with a trend toward bimodality.

Fig. 7 shows the population sex ratio for the months sampled. Departures from a 1:1 ratio occurred in December, August and November. Sex ratios for individuals in naturally occurring pairs did not differ significantly from the population sex ratio for any month sampled (Fig.8).

\section{回 stage 1 血 stage $2 \quad \square$ stage $3 \quad$ stage 4 目 stage 5}

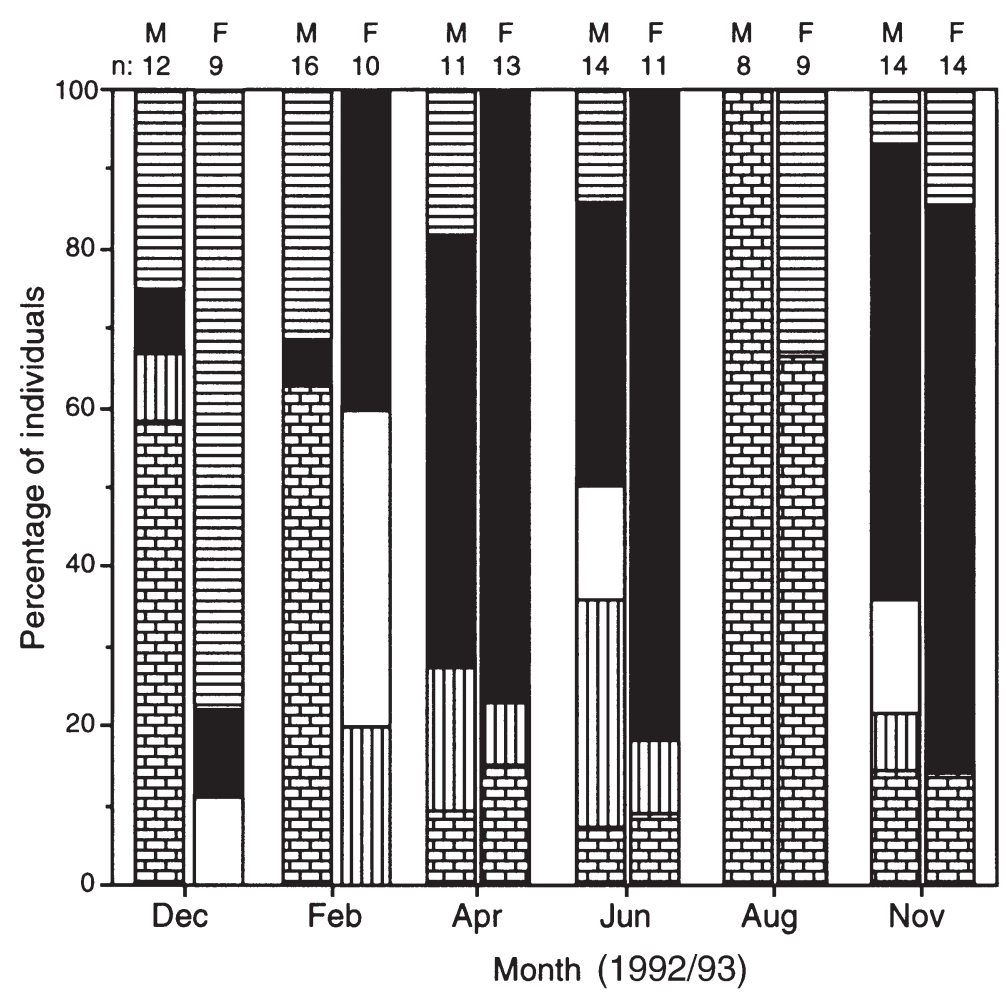

Fig. 5. Lytechinus variegatus. Percentage of individuals at various stages of gonad maturity for each census of the study

\section{Spatial distributions of population}

Throughout the study, sea urchin density varied between 1 and 3 urchins $\mathrm{m}^{-2}$. The largest quadrat size had the highest index of dispersion values for all months except April (Fig. 9). All frequency distributions at this quadrat size were also found to be significantly aggregated when tested against a Poisson distribution (Fig. 9). In December, only urchins at the largest quadrat size were found to be significantly aggregated. There was aggregation at the $1 \mathrm{~m}^{2}$ scale in February and at the $0.25 \mathrm{~m}^{2}$ scale in April. Urchins were significantly aggregated at both of these scales during June, August and November. No significant aggregations were ever found at the smallest $\left(0.06 \mathrm{~m}^{2}\right)$ quadrat size.

The index of dispersion values for each quadrat size are shown plotted against oocyte diameters in Fig. 10. No significant correlations were found between the index of dispersion and oocyte diameter or gonad index at any scale (Table 1). The index for the smallest quadrat size was found to be positively correlated with water temperature and seagrass biomass. There was also a positive correlation with water temperature and the dispersion index at the $0.25 \mathrm{~m}^{2}$ scale, and a negative correlation between urchin size and dispersion index at the $1.00 \mathrm{~m}^{2}$ scale. 


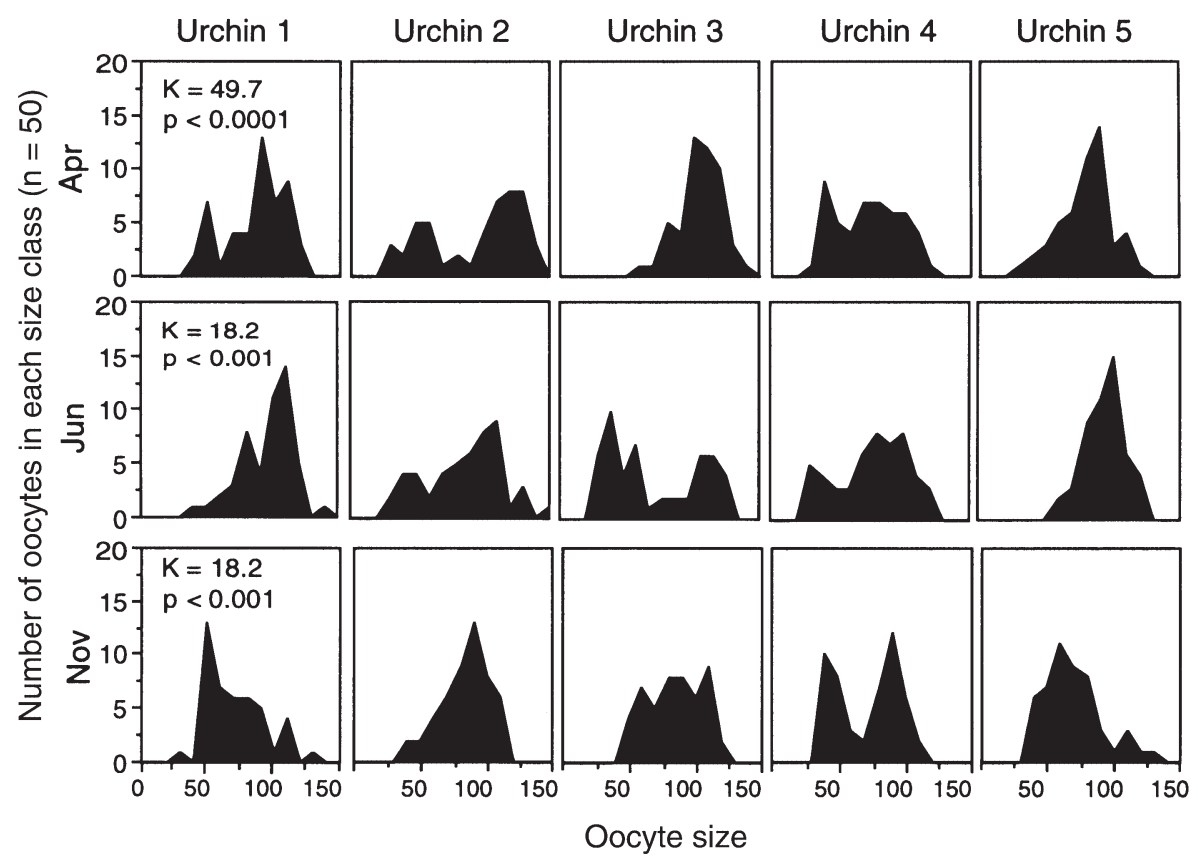

Fig. 6. Lytechinus variegatus. Comparison of oocyte frequency distribution among 5 urchins within censuses. Each census was found to have significant differences in the sizes of oocytes among individual urchins. $\mathrm{K}=$ Kruskal-Wallis statistic

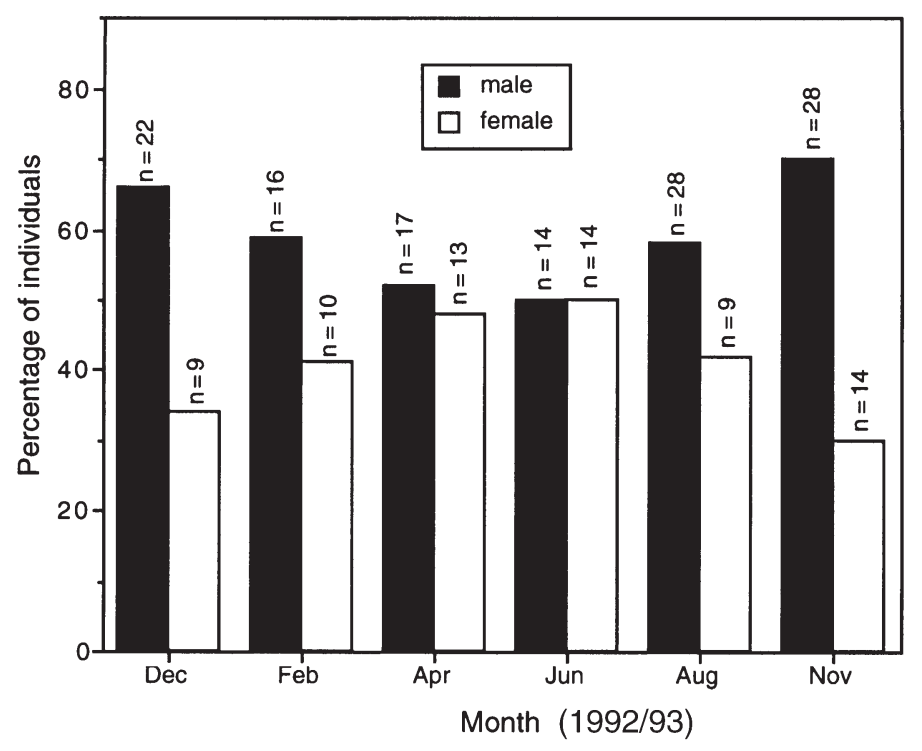

Fig. 7. Lytechinus variegatus. Relative percentage of each sex during each census of the study

Table 1. Lytechinus variegatus. Matrix of Spearman rank correlations between mean indices of dispersion and various factors on different sized quadrats $\left({ }^{*} \mathrm{p}<0.05\right)$

\begin{tabular}{|lllrr|}
\hline \multirow{2}{*}{ Factor } & \multicolumn{4}{c|}{ Quadrat size $\left(\mathrm{m}^{2}\right)$} \\
& 0.06 & 0.25 & 1.00 & 2.00 \\
\hline Oocyte diameter & 0.1539 & -0.0286 & -0.3143 & -0.6377 \\
Water temperature & $0.8721^{*}$ & $0.8286^{*}$ & 0.4286 & -0.2029 \\
Gonad index & 0.1026 & -0.6000 & -0.1429 & 0.5218 \\
Seagrass biomass & $0.8208^{*}$ & -0.4857 & -0.4857 & 0.0580 \\
Urchin size & 0.1539 & -0.6000 & -0.8857 & -0.5508 \\
\hline
\end{tabular}

\section{Movement as a function of aggregation size}

Fig. 11 shows the mean distance traveled for urchins placed in aggregations of different sizes. Movement of urchins in all aggregation sizes varied between 0.5 and $2.5 \mathrm{~m} \mathrm{~d}^{-1}$ and was generally slowest during April and June. There was never a significant difference in distances moved among aggregation sizes. By the $48 \mathrm{~h}$ measurement, the different aggregation sizes had usually mixed completely except in April and June, when movement was the slowest. The mean distances traveled by individual urchins and triplets after $24 \mathrm{~h}$ were positively correlated with gonad index (Spearman rank correlation $R_{s}=0.9122$ and $R_{s}=0.8986$, respectively; Table 2).

The daily mean nearest neighbor distance between urchins placed in different sized aggregations ranged from 20 to $80 \mathrm{~cm}$ (Fig. 12). Both the mean movement rate and the distance between urchins were lowest during the April and June censuses. Urchins dispersed more in the first $24 \mathrm{~h}$ than in the subsequent $2 \mathrm{~d}$. Over the first $24 \mathrm{~h}$, mean distance between urchins was negatively related to mean oocyte diameter $\left(R_{s}=-0.8286\right)$. No other significant correlations were found (Table 3).

No significant differences (log transformed data) were found between the locomotory rates of marked and unmarked urchins (Fig. 13). In the first 10 min both marked and unmarked 

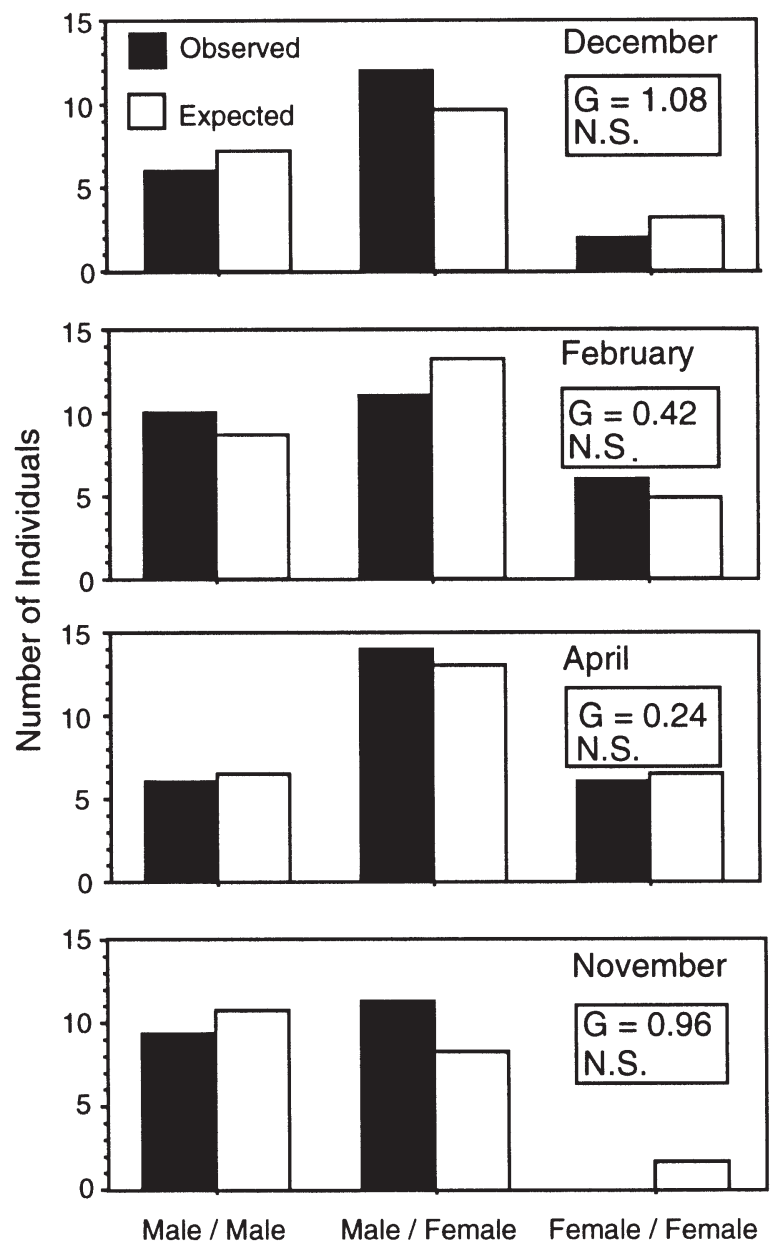

Fig. 8. Lytechinus variegatus. Observed vs expected frequency of homosexual and heterosexual pairing of $L$. variegatus

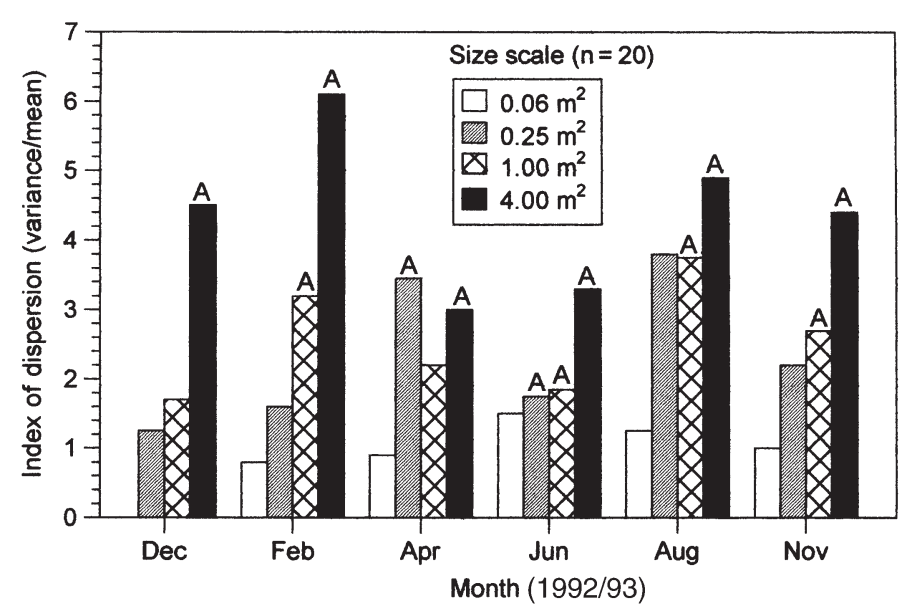

Fig. 9. Lytechinus variegatus. Bimonthly indices of dispersion at 4 different quadrat sizes. The frequency distribution of urchins in each quadrat size was tested against a Poisson distribution as an additional measure of aggregation. $\mathrm{A}=$ significantly aggregated $(\mathrm{p}<0.005)$

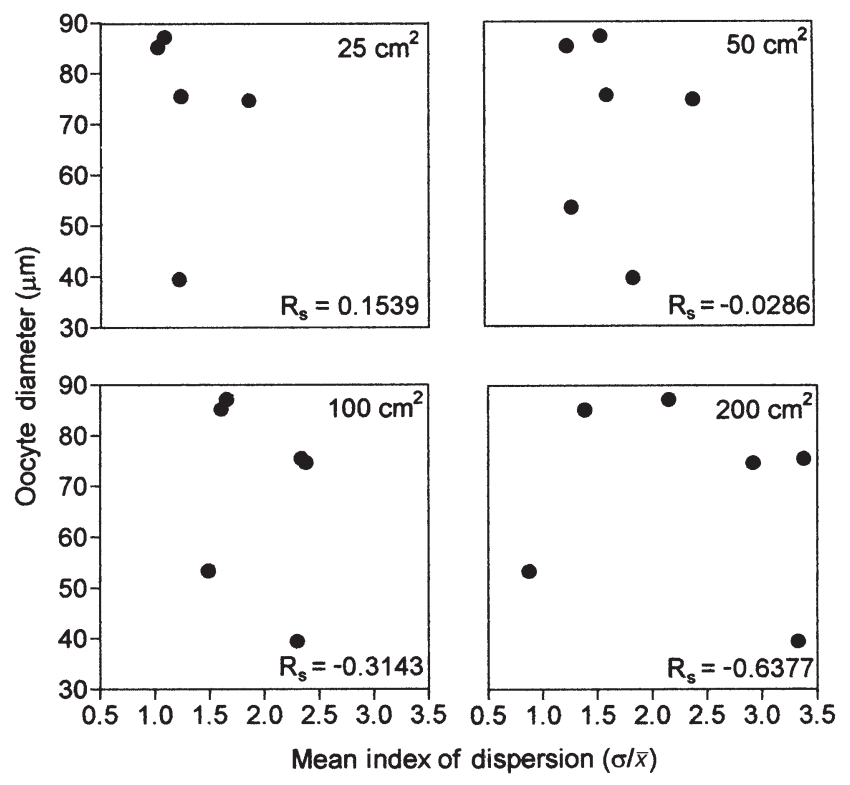

Fig. 10. Lytechinus variegatus. Mean oocyte diameters plotted as a function of dispersion index for 4 spatial scales. $\sigma / \bar{x}=$ variance/mean. Rs = Spearman rank correlation coefficient

Table 2. Lytechinus variegatus. Spearman rank correlation matrix of census means of speed rates of different sized aggregates with various factors on 3 successive days $\left({ }^{*} p<0.05\right)$

\begin{tabular}{|lcrr|}
\hline Factor & \multicolumn{3}{c|}{ Elapsed time (h) } \\
& 24 & 48 & 72 \\
\hline Individuals & & & \\
$\quad$ Water temperature & -0.4414 & 0.0286 & -0.2236 \\
Gonad index & $0.9122^{*}$ & 0.2571 & 0.7826 \\
$\quad$ Seagrass & 0.6179 & -0.2000 & -0.7826 \\
& & & \\
Pairs & & & \\
Water temperature & -0.5798 & -0.0580 & -0.5000 \\
Gonad index & 0.0580 & -0.1160 & 0.5000 \\
Seagrass & -0.3479 & -0.4058 & 0.3000 \\
& & & \\
Triplets & & & \\
$\quad$ Water temperature & -0.5508 & -0.5429 & -0.7000 \\
Gonad index & $0.8986^{*}$ & 0.0857 & 0.3000 \\
Seagrass & 0.6088 & -0.2571 & -0.5000 \\
& & & \\
Quintuplets & & & -0.3000 \\
$\quad$ Water temperature & -0.6377 & -0.1429 & 0.7000 \\
Gonad index & 0.6957 & 0.3714 & 0.2000 \\
Seagrass & 0.2319 & -0.3114 \\
\hline
\end{tabular}

Table 3. Lytechinus variegatus. Spearman rank correlation matrix of census means of nearest neighbor distances of experimentally placed $L$. variegatus with various factors on 3 successive days $(\mathrm{p}<0.05)$

\begin{tabular}{|lrrr|}
\hline Factor & \multicolumn{3}{c|}{ Elapsed time (h) } \\
& 24 & 48 & \multicolumn{1}{c|}{72} \\
\hline Water temperature & -0.0286 & -0.6571 & -0.3000 \\
Gonad index & 0.6000 & 0.2571 & 0.7000 \\
Seagrass & 0.2571 & 0.0857 & 0.1000 \\
\hline
\end{tabular}



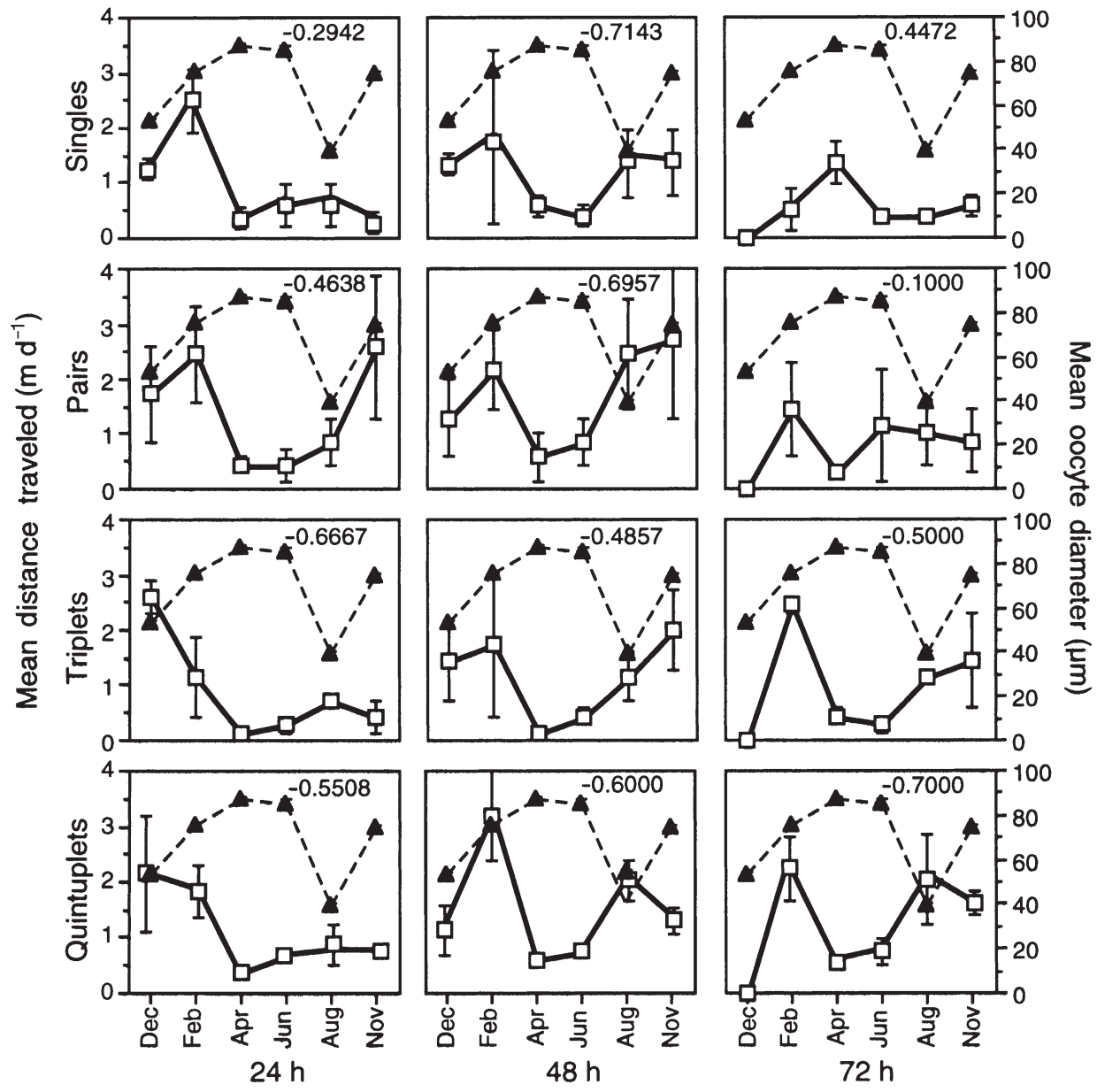

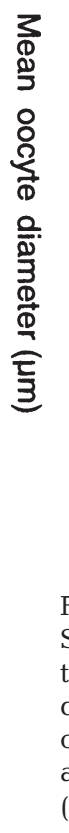

Fig. 11. Lytechinus variegatus. Spearman correlations between the mean of each of 3 successive days of movement $\left(\mathrm{m} \quad \mathrm{d}^{-1}\right)$ of urchins placed in different aggregation sizes, and monthly (1992/93) mean oocyte diameters of the population
Table 4. Lytechinus variegatus. Results of 2-way repeated measures analysis of variance comparing movement of marked and unmarked $L$. variegatus. The movement rate of urchins at 10 and 60 min was the repeated measure

\begin{tabular}{|lccccc|}
\hline Source & $\mathrm{SS}$ & $\mathrm{df}$ & $\mathrm{MS}$ & F-ratio & $\mathrm{p}$ \\
\hline Between subjects & & & & & \\
$\quad$ Marking treatment & 0.0396 & 1 & 0.0396 & 0.0269 & 0.5986 \\
$\quad$ Month & 2.7927 & 3 & 0.9303 & 0.6313 & 0.5986 \\
$\quad$ Marking treatment & 1.9973 & 3 & 0.6658 & 0.4515 & 0.7175 \\
$\quad \times$ Month & & & & & \\
$\quad$ Error & 67.8350 & 46 & 1.4747 & & \\
$\quad$ & & & & \\
$\quad$ Within subjects & 20.1784 & 1 & 20.1784 & 69.3951 & 0.0000 \\
$\quad$ Time & 0.2910 & 1 & 0.2910 & 1.0008 & 0.3224 \\
$\quad$ Time $\times$ Marking & & & & & \\
$\quad$ treatment & 1.2517 & 3 & 0.4172 & 1.4349 & 0.2448 \\
$\quad$ Time $\times$ Month & 2.1052 & 3 & 0.7017 & 2.4134 & 0.0787 \\
$\quad$ Time $\times$ Marking & & & & & \\
$\quad$ treatment $\times$ Month & 13.3757 & 46 & 0.2908 & & \\
$\quad$ Error & & & & & \\
\end{tabular}

urchins moved at a rate that varied between 0.5 and $2.5 \mathrm{~cm} \mathrm{~min}^{-1}$. After $60 \mathrm{~min}$ had elapsed, the locomotory rate for both treatments had significantly decreased to 0.25 and $0.75 \mathrm{~cm} \mathrm{~min}^{-1}$ (Table 4).

\section{DISCUSSION}

\section{Reproductive periodicity}

During this 1 yr study, Lytechinus variegatus in Biscayne Bay had a long reproductive season in the spring and a shorter reproductive season with generally smaller oocytes in the fall. Our fall census must have taken place at about the reproductive peak, because gonadal sections had little nutritive tissue remaining. The lower 


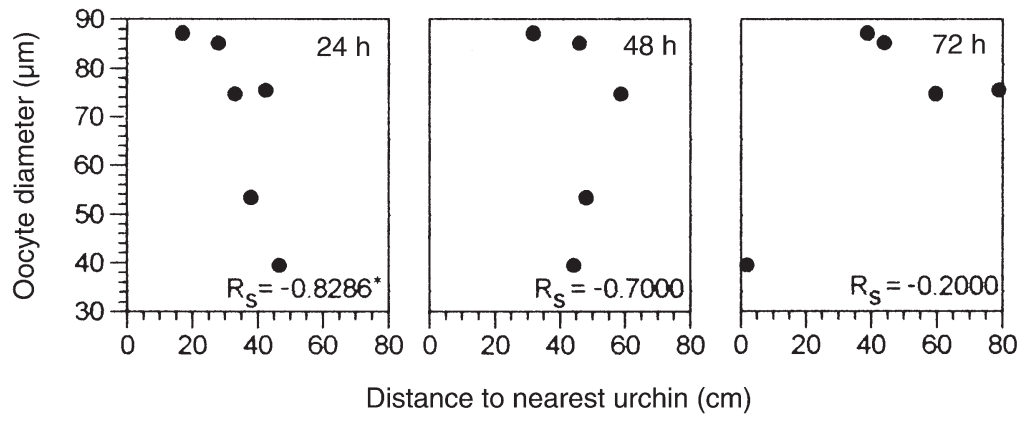

Fig. 12. Lytechinus variegatus. Relationship between nearest neighbor distance and oocyte diameters of marked urchins on 3 successive days $\left({ }^{*} p<0.05\right)$

made during the reproductive seasons. Some distributions were skewed toward smaller or larger oocytes, while others contained bimodal distributions with 2 obviously separate cohorts of eggs being produced. This natural variation in oocyte size distribution could be caused by differences in local food availability. Beddingfield \& McClintock (1998, 2000) suggested that local differences in food availability were responsible for reproductive variability observed in populations of Lytechinus variegatus in St. Joseph's Bay, Florida. However, this seems unlikely,

gonad index in the fall suggests that the fewer gametes were spawned in the fall than during the spring.

These conclusions are supported by 2 of the 3 techniques used in this study for determining reproductive state. Thus, gonad classification and oocyte size frequency distributions were suggestive of 2 spawning seasons in spring and fall, whereas the gonadal indices indicate reproductive peaks in December and February, with a reproductive low occurring by April. Moore \& Lopez (1972), who censused a population near Key Biscayne for $10 \mathrm{yr}$ (using gonadal indices based on volumes), observed 1 primary reproductive peak each year, but the peak varied within the winter and spring time periods. Despite these confusing differences, we are inclined to trust our finding of 2 reproductive peaks for the year we studied. As independent evidence, we found it easiest to induce spawning by KCL injection during the 2 peaks revealed by gonad analyses. A similar bimodal reproductive pattern has been observed in several Lytechinus variegatus populations on the west coast of Florida (Ernest \& Blake 1981).

Oocyte size frequency distributions varied among female urchins during all collections, including those

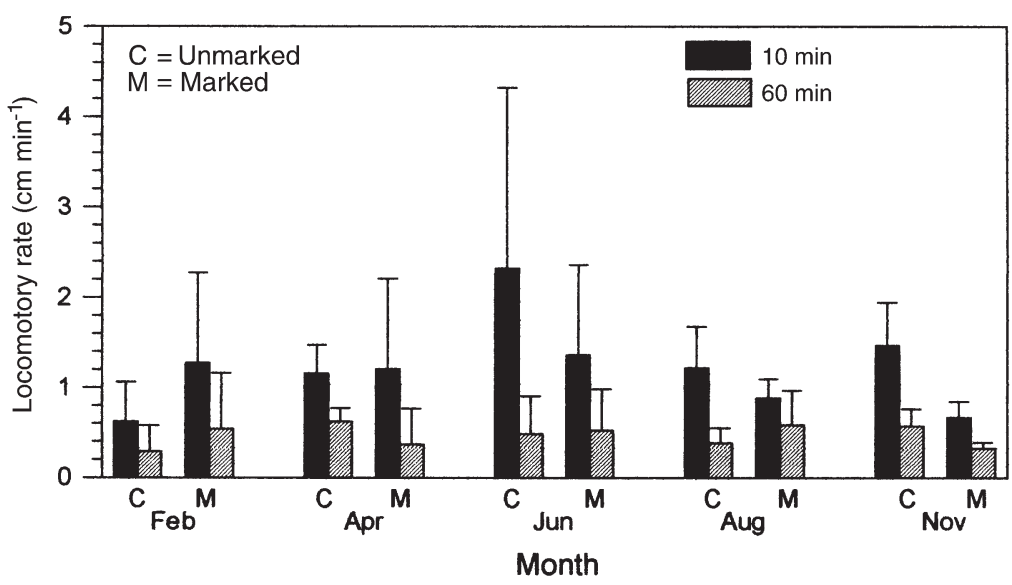

Fig. 13. Lytechinus variegatus. Locomotory rates of marked and unmarked urchins after 10 and 60 min time periods even considering the prodigious grazing abilities of these sea urchins (Camp et al. 1973, Garnick 1978, Vadas et al. 1986, Valentine \& Heck 1991), as seagrass was always abundant and fairly uniform at the study sites. A more likely alternative explanation is that cohorts of eggs are shed sporadically during a relatively long period of reproductive activity. Several populations of $L$. variegatus apparently spawn repeatedly during reproductive seasons that may or may not be linked to lunar phases (Moore et al. 1963, Moore \& Lopez 1972, Lessios 1991). Even if mass spawning occurs repeatedly, however, it may be obscured by numerous small scale spawning events that occur throughout the reproductive season. The end of the spring reproductive season is marked by the greatest variation among individuals, because this is a transitional period when some urchins have recently spawned and others have gametes in early stages of gametogenesis. Therefore, it appears unlikely that the oocyte variation observed during this period is caused by a large scale mass spawning.

There appears to be a seasonal shift in the ratio of males to females in the population of Lytechinus variegatus at Key Biscayne. This shift could be artifactual if the only data collected were based on those that spawned. However, if this error were present, the number of females should be higher than the number of males because females become ripe before the males. This was not the case. Although the data are limited, seasonal shifts in sex ratio have been noted previously in this species (Moore et al. 1963, Brookbank 1968). The actual mechanism by which this shift occurs is unclear, but 1 possibility is a gender-specific migration. Moore et al. (1963) suggested that cold temperature shock might have been responsible for a large percentage of the population becoming hermaphroditic following an unusually cold winter of 1957 to 1958 . While hermaphroditic go- 
nads contained predominately testes at the beginning of the year, the proportion of female tissue increased during the course of the year. A year later, hermaphrodites had disappeared from the population. It is significant that the normally skewed sex ratio became 1:1 during both reproductive peaks we observed.

The frequency of homosexual and heterosexual pairing was found to be random based on the population's sex ratio for each census taken. This has also been found in other studies investigating pairing behavior of echinoids (Young et al. 1992) although some asteroids can apparently discriminate between genders (Komatsu 1981, Run et al. 1988). We found no evidence for small scale aggregations that lasted throughout the reproductive season. The few natural pairs observed occurred randomly and apparently lasted for only brief periods. This might be expected if spawning occurs sporadically during short encounters. Because the population density is relatively high, individuals may be able to spawn a little with each conspecific encountered. Although this might waste $50 \%$ of the gametes (to homosexual pairings), it would ensure genetic variability in the population.

\section{Spatial distributions of populations}

The density of Lytechinus variegatus off southern Virginia Key varied seasonally from 1 to 3 urchins $\mathrm{m}^{-2}$. These are relatively low densities compared with those of other L. variegatus populations in Biscayne Bay and elsewhere (Moore et al. 1963, Moore \& McPherson 1965, Camp et al. 1973, Greenway 1976, Montague et al. 1977, Rivera 1978, Engstrom 1982, Vadas et al. 1982, Keller 1983, Valentine \& Heck 1991, Beddingfield \& McClintock 2000). Despite this, the density should be sufficient for high fertilization success during a mass spawning event if we can assume that the fertilization kinetics are similar to those of previously studied echinoid species (Pennington 1985, Levitan 1991b, Levitan et al. 1992, Levitan \& Young 1995). The population density is also high enough to facilitate numerous intraspecific encounters during the course of a reproductive season lasting several months.

Urchins aggregated at times on every spatial scale measured, but the only significant annual trend occurred at the largest size scale $\left(2.00 \mathrm{~m}^{2}\right)$. Aggregations at this scale were most evident just before periods of spawning. Noticeably different amounts of seagrass in the guts of urchins during these same time periods suggest that these aggregations could be related to feeding. Several observations (Witman et al. 1982, Vadas et al. 1986, Unger \& Lott 1994) of large scale aggregations have been attributed to patchy food sources. Garnick (1978) speculated that during the course of feeding, chemicals released into the water by algal foods attract Strongylocentrotus drobachiensis into large aggregations. Large aggregations of Lytechinus variegatus may be the result of attractions that are caused by increased feeding activity but not in the same manner. Klinger \& Lawrence (1985) suggest that L. variegatus cannot sense food at a distance and must find food by random movement. Thus, any aggregations formed for feeding are probably formed by random encounters. These aggregations could also represent a defensive response to a seasonal predator. Aggregation is known to serve as a defensive tactic by some species of echinoids (Pearse \& Arch 1969). Possibly these aggregations represent some other type of social behavior that we are unaware of.

Distinct seasonal reproductive aggregations of Lytechinus variegatus were not found at any spatial scale, either in our study or in a recent study in St. Joseph's Bay, Florida (Beddingfield \& McClintock 2000). Therefore, if behavior facilitating spawning exists, it must occur at smaller temporal scales than our sampling program was capable of resolving.

The overriding tendency of Lytechinus variegatus was to aggregate at the larger spatial scales. Although a trend of increasing significance in measures of aggregation occurred just prior to reproductive peaks, large scale aggregations were significant throughout the year. The frequency of small scale aggregations (e.g. pairs) was found to be very low throughout the study.

Some deep-sea echinoderms that have low densities form long lasting pairs during the reproductive season, perhaps because the chance of finding a mate is low (Young et al. 1992). The drawback with this strategy is that while reproduction is ensured, genetic exchange is not as likely to occur among members of the population. A species such as $L$. variegatus that lives at higher densities might not be expected to show the same kind of reproductive behavior, as they should be able to reproduce successfully by either mass spawning or spawning on a small scale during numerous intraspecific encounters.

\section{Movement as a function of aggregation size}

In all field experiments, Lytechinus variegatus exhibited continuous movement with no increase in intraspecific encounter rates during the reproductive season. Moreover, it is very likely that all urchins really moved greater distances than the linear distances of 1 to $3 \mathrm{~m} \mathrm{~d}^{-1}$ measured. Klinger (1984) observed similar daily rates of movement ( 0.96 to $4.32 \mathrm{~m} \mathrm{~d}^{-1}$ ) for $L$. variegatus on the West coast of Florida. These rates are similar to movement rates of several other echinoid species, which range from 0.5 to $2 \mathrm{~m} \mathrm{~d}^{-1}$ (Camp et al. 
1973, Mattison et al. 1977, Garnick 1978). The only significant correlations involving movement were found in the single and triplet urchin treatments, where rate of movement was correlated with gonad index at $24 \mathrm{~h}$.

There were several general seasonal trends in movement and dispersion with the experimental aggregations of urchins. During the April and June censuses, movement rates were slow. This change in behavior could have been in response to water contamination caused by a ruptured sewer line 3 wk earlier and which caused the census to be postponed. This seems unlikely, however, because if the contaminated water was detrimental to the population, the urchins at all sites should have been affected similarly. All were in close proximity and approximately the same distance from shore. During these 2 months, we observed the most advanced gametogenic state and largest mean oocyte diameter, suggesting that slow dispersal may represent a true reproductive behavior. During the November reproductive peak, oocyte diameter was slightly smaller. Perhaps urchins had not quite reached maximum maturity.

The high abundance of urchins in the shallow water during December probably represents a one-time event rather than a seasonal trend. Several months before this study began, the eye of Hurricane Andrew passed approximately $5 \mathrm{~km}$ south of the study sites. The storm, which had maximum sustained winds of $270 \mathrm{~km} \mathrm{~h}^{-1}$, directed waves as high as $5.3 \mathrm{~m}$ above sea level towards the sites on the southwestern shore of Virginia Key (Pimm et al. 1994). Urchins dislodged and moved into shallow water would have required several months to re-establish the relatively deeper water populations while moving randomly at 1 to $3 \mathrm{~m} \mathrm{~d}^{-1}$.

The number of observed intraspecific encounters did not differ appreciably through the year for any of the field experiments. Touching aggregations were seldom found to remain together longer than $48 \mathrm{~h}$ and most remained together no longer than $24 \mathrm{~h}$. However, encounters apparently lasted longer when there were more total urchins. In several of these intraspecific encounters, pairs and triplets moved together, in one case for a distance of $2 \mathrm{~m}$. In April, many of these marked urchins were injected with $0.55 \mathrm{M} \mathrm{KCl}$ to ascertain whether they were ripe or not. All urchins, whether isolated or in small scale aggregations were found to be ripe during the reproductive season.

Gametogenesis and behavior facilitating reproduction in the Lytechinus variegatus population off the southeast shore of Virginia Key in Biscayne Bay, Florida suggest that sporadic spawning occurs often during a relatively long reproductive season in the spring and a shorter one in the fall. Long term (seasonal) small scale aggregations for mass spawning therefore seem unlikely. Short term aggregations for spawning, however, might exist. The density and movement of $L$. vareigatus is high enough to result in numerous intraspecific encounters even if movement is completely random. Indeed, each urchin is likely to experience numerous encounters during the relatively long reproductive season. This might result in short term reproductive aggregations of no more than a few days as in Sphaerechinus granularis (Unger \& Lott 1994). L. variegatus appear less likely to disperse when oocytes reach very large sizes, which leads to the speculation that aggregation may be a very short term behavioral mechanism to improve fertilization success when the proper external cues, such as gametes, induce spawning.

Acknowledgements. We would like to thank G. Dinesen, J. Richard and P. Richards for assistance in the field. This work was supported by NSF Grant OCE-9116560 and is Harbor Branch Contribution Number 1402.

\section{LITERATURE CITED}

Andrew NL, Mapstone BD (1987) Sampling and the description of spatial pattern in marine ecology. Oceanogr Mar Biol Annu Rev 25:39-90

Beddingfield SD, McClintock JB (1998) Differential survivorship, reproduction, growth and nutrient allocation in the regular echinoid Lytechinus variegatus (Lamark) fed natural diets. J Exp Mar Biol Ecol 226:195-215

Beddingfield SD, McClintock JB (2000) Demographic characteristics of Lytechinus variegatus (Echinoidea: Echinodermata) from three habitats in a North Florida Bay, Gulf of Mexico. PSZN I:Mar Ecol 21:17-40

Brazeau DA, Lasker HR (1990) Sexual reproduction and external brooding by the Caribbean gorgonian Briareum asbestinum. Mar Biol 104:465-474

Brookbank JW (1968) Spawning season and sex ratio of echinoids. Q J Fla Acad Sci 307:177-183

Camp DK, Cobb SP, Breedveld JFW (1973) Overgrazing of seagrasses by a regular urchin Lytechinus variegatus. Bioscience 23:37-38

Denny MW (1988) Biology and mechanics of the waveswept environment. Princeton University Press, Princeton, NJ, p 133-152

Denny MW, Shibata MF (1989) Consequences of surf-zone turbulence for settlement and external fertilization. Am Nat 134:859-889

Dix TG (1969) Aggregating in the echinoid Evechinus chloroticus. Pac Sci 23:123-124

Elmhirst R (1922) Habits of Echinus esculentus. Nature 110:667

Engstrom NA (1982) Immigration as a factor in maintaining populations of the sea urchin Lytechinus variegatus (Echinodermata: Echinoidea) in seagrass beds on the southwest coast of Puerto Rico. Stud Neotrop Fauna Environ 1:51-60

Ernest RG, Blake NJ (1981) Reproductive patterns within subpopulations of Lytechinus variegatus (Lamark) (Echinodermata: Echinoidea). J Exp Mar Biol Ecol 55:25-37

Garnick E (1978) Behavioral ecology of Stronylocentrotus drobachiensis (Muller) (Echinodermata: Echinoidea). Oecologia 37:77-84 
Giese AC, Kanatani H (1987) Maturation and spawning. In: Giese AC, Pearse JS Pearse JB (eds) Reproduction of marine invertebrates, Vol IX. General aspects: seeking unity in diversity. Blackwell Science, Oxford, p 251-329

Grant A, Tyler PA (1983) The analysis of invertebrate reproduction. II. The analysis of oocyte size/frequency data, and comparison of different types of data. Int J Invertebr Reprod 6:271-283

Grassle JF, Sanders HF, Hessler RR, Rowe GT, McLella T (1975) Pattern zonation: a study of the bathyal megafauna using the research submersible Alvin. Deep-Sea Res 22:457-481

Greenway M (1976) The grazing of Thalassia testudinum in Kingston Harbour, Jamaica. Aquat Bot 2:117-126

Keller BD (1983) Coexistence of sea urchins in seagrass meadows, an experimental analysis of competition and predation. Ecology 64:1581-1598

Klinger TS (1984) Feeding of a marine generalist grazer: Lytechinus variegatus (Lamark) (Echinodermata: Echinoidea). PhD thesis, University of South Florida, Tampa

Klinger TS, Lawrence JM (1985) Distance perception of food and the effect of food quantity on feeding behavior of Lytechinus variegatus (Lamark) (Echinodermata:Echinoidea). Mar Behav Physiol 11:327-344

Komatsu M (1983) Development of the sea star, Archaster typicus, with a note on male on female superposition. Annot Zool Jpn 56:187-195

Krebs CJ (1989) Ecological methodology. Harper Collins Publishers, New York, p 16-166

Lessios HA (1991) Presence and absence of monthly reproductive rhythms among eight Caribbean echinoids off the coast of Panama. J Exp Mar Biol Ecol 153:27-47

Levitan DR (1988) Asynchronous spawning and aggregative behaviour in the sea urchin Diadema antillarum Philippi. In: Burke RD (ed) Proc 6th Int Echinoderm Conf. AA Balkema, Rotterdam, p 181-186

Levitan DR (1991a) Influence of body size and population density on fertilization success and reproductive output in a free-spawning invertebrate. Biol Bull 181:261-268

Levitan DR (1991b) Kinetics of fertilization in the sea urchin Strongylocentrotus franciscanus: Interaction of gamete dilution, age, and contact time. Biol Bull 18:371-378

Levitan DR (1995) The ecology of fertilization in free-spawning invertebrates. In: McEdward L (ed) Ecology of marine invertebrate larvae. CRC Press, Boca Raton, FL, p 123-156

Levitan DR, Young CM (1995) Fertilization success in large populations: empirical measures and theoretical predictions of fertilization success in Clypeaster rocaceus. J Exp Mar Biol Ecol 190:221-241

Levitan DR, Sewell MA, Chia FS (1992) How distribution and abundance influence fertilization success in the sea urchin Strongylocentrotus franciscanus. Ecology 73:248-254

Lewis JB (1958) The biology of the tropical sea urchin Tripneustes esculentus Leske in Barbados, British West Indies. Can J Zool 36:607-621

Mattison JE, Trent JD, Shanks AL, Akin TB, Pearse JS (1977) Movement and feeding activity of Red Sea Urchins (Strongylocentrotus franciscanus) adjacent to a kelp forest. Mar Biol 39:25-30

Montague JR, Ortiz L, Arguelles L, Millan J, Cardoch L (1977) Density and dispersion estimates for sea urchins in a south Florida seagrass community. Bio Sci 51:19-22

Moore HB, Lopez NN (1972) Factors controlling the seasonal

Editorial responsibility: Kenneth Heck (Contributing Editor), Dauphin Island, Alabama, USA spawning pattern of Lytechinus variegatus. Mar Biol 14: $275-280$

Moore HB, McPherson BF (1965) A contribution to the study of the productivity of the urchins Tripneustes esculentes and Lytechinus variegatus. Bull Mar Sci 15:855-871

Moore HB, Jutare T, Bauer JC, Jones JA (1963) The biology of Lytechinus variegatus. Bull Mar Sci Gulf Caribb 13:23-53

Orton JH (1914) On the breeding habits of Echinus miliaris, with a note on the feeding habits of Patella vulgata. J Mar Biol Assoc UK 10:254-257

Pearse JS, Arch SW (1969) The aggregation behavior of Diadema (Echinodermata, Echinoidea). Micronesica 5:165-171

Pennington JT (1985) The ecology of fertilization of echinoid eggs: the consequences of sperm dilution, adult aggregation, and synchronous spawning. Biol Bull 169:417-430

Pimm SL, Davis GE, Loope L, Roman CT, Smith TJ III, Tilmant JT (1994) Hurricane Andrew. Bioscience 44:224-229

Rivera JA (1978) Aspects of the biology of Lytechinus variegatus (Lamark, 1816) at Jobos Bay, Puerto Rico (Echinoidea: Toxopneustidae). MSc thesis, University of Puerto Rico, Mayaguez

Run JQ, Chen CP, Chang KH, Chia FS (1988) Mating behavior and reproductive cycle of Archaster typicus (Echinodermata: Asteroidea). Mar Biol 99:247-253

Sewell MA, Levitan DR (1992) Fertilization success during a natural spawning of the dendrochirote sea cucumber Cucumaria miniata. Bull Mar Sci 51:161-166

Sokal RR, Rohlf FJ (1995) Biometry: the principles and practice of statistics in biological research, 3rd edn. WH Freeman and Co, New York

Thorson G (1950) Reproductive and larval biology of marine bottom invertebrates. Biol Rev 25:1-45

Tyler PA, Young CM (1992) Reproduction in marine invertebrates in 'stable' environments: the deep sea model. Invertebr Reprod Dev 22:185-192

Tyler PA, Young CM, Billett DSM, Giles LA (1992) Pairing behaviour, reproduction and diet in the deep-sea holothurian genus Paroriza (Holothurioidea: Synallactidae). J Mar Biol Assoc UK 72:447-462

Unger B, Lott C (1994) In-situ studies on the aggregation behaviour of the sea urchin Sphaerechinus granularis LAM (Echinodermata: Echinoidea). In: Bruno DA, Guille A, Feral JP, Roux M (eds) Proc 8th Int Echinoderm Con, Dijon, France. AA Balkema, Rotterdam, p 913-917

Vadas RL, Elner RW, Garwood PE, Babb IG (1986) Experimental evaluation of aggregation behavior in the sea urchin Strongylocentrotus drobachiensis: a reinterpretation. Mar Biol 90:433-448

Valentine JF, Heck KL Jr (1991) The role of sea urchin grazing in regulating subtropical seagrass meadows: evidence from field manipulations in the northern Gulf of Mexico. J Exp Mar Biol Ecol 154:215-230

Witman JD, Hulbert AH, Harris LG (1982) Morphology of a sea urchin front (Strongylocentrotus drobachiensis) at the Isles of Shoals, N.H. In: Lawrence JM (ed) Proc 4th Int Echinoderm Con, Tampa Bay. AA Balkema, Rotterdam, p 285

Young CM, Tyler PA, Cameron JL, Rumrill SG (1992) Seasonal breeding aggregations in low-density populations of the bathyal echinoid Stylocidaris lineata. Mar Biol 113:603-612

Yund P (1990) An in-situ measurement of sperm dispersal in a colonial marine hydroid. J Exp Zool 253:102-106

Submitted: May 5, 2001; Accepted: September 19, 2001

Proofs received from author(s): April 22, 2002 